\title{
KEPRIBADIAN MANUSIA PERPEKTIF AL-QURAN (Pendekatan Tafsir dan Ilmu Psikologi)
}

\author{
Supriadi $^{1}$
}

ucup.priadi@gmail.com

\begin{abstract}
ملخص

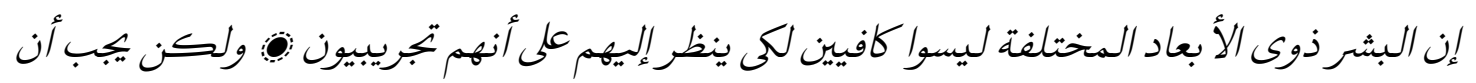

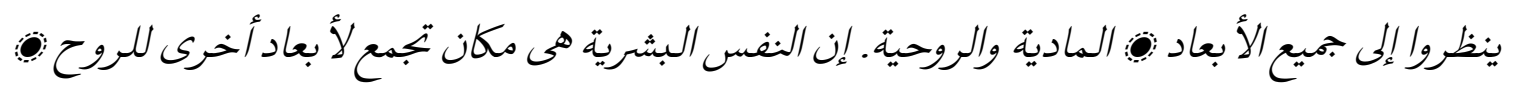

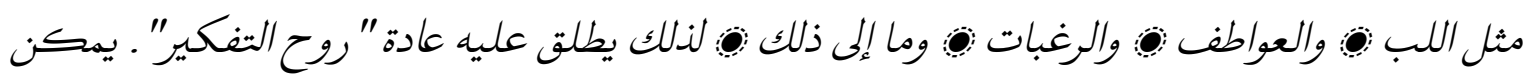

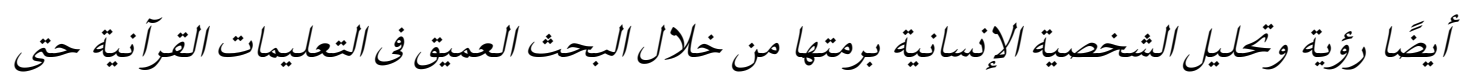
يمكن صياغة إنسان كمل أوقرآن إنسانى.
\end{abstract}

المعرفة كنزمن الثروة العقلية التى ثثرى حياتنا بطريقة غير مباشرة. العلوم والفلسفة والدين هي أنساء أجزاء

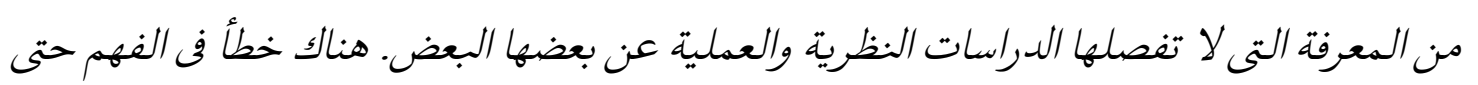
تكون التصادمات بين هذه الأنواع الثلاثة من المعرفة حتمية.

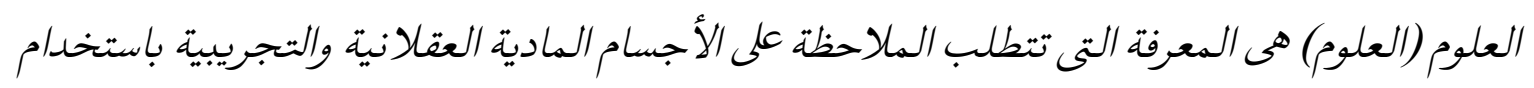

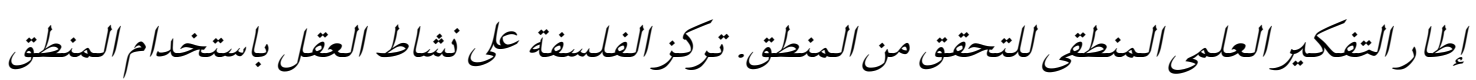

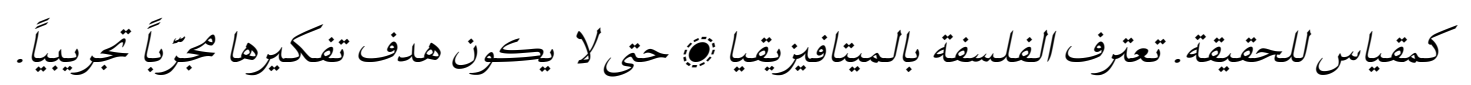

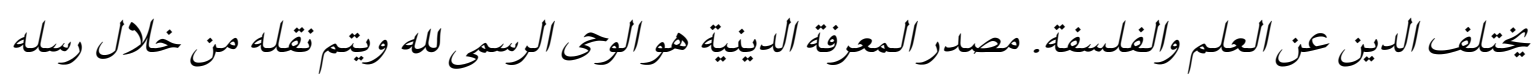

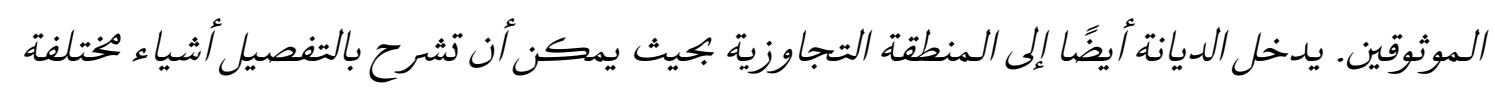
خارج نطاق العلم وحتى الفلسفة.

تحاول هذه الورقة دراسة العلوم والفلسفة والدين باستخدام بنية الفلسفة $ه$ وهى علم الوجود (الجوهم) ف ونظرية المعرفة (طريقة الحصول عليها) والمقصورية (الاستخدام والقيمة).

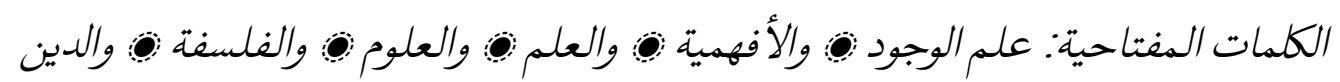

\footnotetext{
${ }^{1}$ Dosen Tetap Prodi PAI STAI Asy-Syukriyyah
} 


\section{Jurnal Asy-Syukriyyah}

\section{Pendahuluan}

Al-Qur'an menggunakan beberapa istilah untuk menunjuk makna manusia, yaitu: bani adam, dzurriyat adam (keturunan adam, anak adam), al-insan, al-ins, al-nas, atau unas, dan al-basyar. Sementara menurut sebagian mufassir kata al- basyar digunakan untuk menyebut manusia secara fisik, sebagai makhluk yang memiliki segala sifat kemanusiaan dan keterbatasan, seperti makan, minum, seks, keamanan, kebahagiaan, dan lain sebagainya. Penunjukan kata al-basyar ditujukan Allah kepada seluruh manusia tanpa terkecuali, termasuk eksistensi Nabi dan Rasul. Sementara al-nas adalah nama manusia sebagai spesies, sedangkan al-insan melebihi intensi makna yang ada, yaitu manusia sebagai satu-satunya yang pantas menjadi khalifah di bumi dan menerima taklif serta amanat karena telah dibekali ilmu, al-bayan, al-agi dan al-tamyiz."

Setiap jenis pengetahuan mempunyai ciri-ciri yang spesifik mengenai apa (ontologi), bagaimana (epistemologi), dan untuk apa (aksiologi) pengetahuan itu disusun. ${ }^{2}$ Pengetahuan pada hakikatnya merupakan segenap apa yang diketahui oleh manusia tentang suatu objek tertentu, termasuk di dalamnya adalah ilmu, filsafat, seni, agama, dan berbagai pengetahuan lainnya. ${ }^{3}$

Tinjauan al-Qur'an terhadap konsep manusia bisa dilihat dari dua sudut pandang yang berbeda yaitu sudut pandang hubungan manusia dengan Allah ( abdullah) dan hubungannya dengan lingkungan ( khalifatullah).

Diberikannya kemampuan akal, ilmu, dan kemampuan membedakan baik-buruk menjadikan manusia lebih "sempurna" dari makhluk ciptaan lain. Allah mewujudkan eksistensi manusia di bumi dalam perannya sebagai seorang khalifah yang bertugas menjalankan amanah dan bertanggung jawab terhadap seluruh kewajiban yang dibebankan.

Tiga landasan di atas (ontologi, epistemologi dan aksiologi) akan digunakan penulis sebagai pendekatan dalam menjabarkan secara mendalam mengenai ilmu, filsafat dan agama. Pada akhirnya bisa dilihat jalinan dari ketiga hal tersebut. Itulah yang menjadi tujuan utama dalam penulisan ini, agar menjadikan al-Qur'an sebagai hudan adalah fakta.

Metode dalam penelitian ini menggunakan deskripsi analysis, yaitu melihat dari segala aspek seperti tafsir, filsafat, psikologi dan sosial.

${ }^{2}$ Jujun S. Suriasumantri, Filsafat Ilmu: Sebuah Pengantar Populer, Jakarta: Pustaka Sinar Harapan, 2013, cet. ke-24, h. 104

${ }^{3}$ Jujun S. Suriasumantri, Filsafat Ilmu, h. 105 


\section{Kepribadian Manusia Menurut Psikologi Modern}

Berbagai mazhab kepribadian dalam dunia psikologi modern lahir dari kerangka keilmiahan yang menjadi basis penelusuran para teoritikus kepribadian barat, maka merekapun mengalami keterbatasan dalam proses analisis dan sintesis akan konsepsi kepribadian manusia secara menyeluruh. Mereka mengalami banyak kesulitan dalam mengurai hal-hal yang berada di luar rasionalitas manusia, yakni hal-hal yang berbau metafisik. Hal tersebut tampak dalam tiga aliran mainstream psikologi modern; aliran Psikoanalisa (Freud), aliran Behaviorisme (Skinner), dan aliran psikologi Humanistik.

\section{Aliran Psikoanalisa (Sigmund Freud)}

Aliran ini menekankan analisis struktur kepribadian manusia yang relatif stabil dan menetap. Dalam perspektif aliran ini, manusia memiliki tiga struktur kepribadian; aspek biologis (struktur id), psikologis (struktur ego), dan sosiologis (struktur super ego). ${ }^{4}$ Ketika manusia dilahirkan, ia hanya mempunyai id atau dorongan-dorongan yang minta dipuaskan. Dalam perkembangan selanjutnya, tumbuhlah superego dalam diri manusia. Superego terbentuk ketika seseorang berinteraksi dengan orang lain. Antara id dan superego selalu muncul pertentangan. Id mewakili kepentingan pribadi, sementara superego mewakili norma-norma masyarakat. Untuk mengatur mekanisme keduanya, kemudian berperanlah ego.

Freud meyakini, bahwa penggerak utama kesadaran manusia adalah insting hidup yang disebut dengan IIbido, sedang IIbido yang paling dominan adalah IIbido seksual yang terletak pada struktur id (aspek biologis manusia). Saking kuatnya dorongan IIbido seksual yang ada dalam diri manusia, sehingga ia mengatasi alam pikiran serta ruang gerak manusia. ${ }^{5}$ Menurut Freud, alam pikiran dan ruang gerak manusia bersumber dari adanya kekuatan IIbido yang dispesifikasikan sebagai dorongan seksual. Dan semua gangguan psikis adalah akibat konflik seksual dari kekuatan IIbido yang tidak tersalurkan dengan baik. Untuk itu, terapi ala Freud digiring pada prinsip kesenangan dan prinsip realitas, tanpa memperhatikan normanorma ketuhanan. Ia beranggapan, bahwa agama terlalu banyak mengadakan laranganlarangan kepada manusia, dan dianggap sebagai penghalang tersalurnya tekanan-

${ }^{4}$ Calvin S. Hall, A Primer of Freudian Psychology, New York: The World Publishing, 1954, h. 22

${ }^{5}$ Calvin S. Hall and Gardner Lindzey, Theories of Personality, Second Edition. New York: John Wiley and Sond, Inc., 1970, h 130 
tekanan psikologis. Oleh Freud, tekanan-tekanan yang mengendap di bawah sadar itu disalurkan lewat logika akal. Kumpul kebo misalnya, oleh Freud bisa diterima sebagai "katup pengaman" tersalurnya tekanan-tekanan seksual. ${ }^{16}$

Dalam pandangan psikoanalisa Freud -sebagaimana pandangan sains pada umumnya- manusia hanyalah sebagai makhluk biologis semata. Manusia hidup, lahir dan berkembang hanyalah sebagai akibat bekerjanya daya-daya kosmik terhadap benda-benda inorganik. Pemikiran ini jelas sangat dipengaruhi pemikiran Charles Darwin bahwa manusia tak lebih dan tak kurang hanyalah binatang. Oleh karenanya, manusia menjadi tidak lagi berbeda dengan makhluk hewan yang bergerak hanya atas dasar instingnya saja yang bernama eros (instink hidup) dan tanatos (instink mati). Atau dengan kata lain, dalam pandangan Freud, manusia tidak memiliki nilai kebaikan dalam dirinya. ${ }^{7}$ Ketika lahir, manusia hanya memiliki nafsu atau IIbido atau id.

Dengan kata lain, seluruh tingkah manusia dalam pandangan aliran ini menjadi teraktual oleh karena IIbido seksual ini. Hal ini menunjukan bahwa aktualisasi aspek psikologis dan sosiologis manusia hanya dimotivasi oleh peran seks (syahwat). Untuk itu, hakikat tujuan hidup manusia manurut Freud hanya mengejar kenikatan, hedonisme dan mengembangkan impuls-impuls hawa nafsunya yang primitif, bukan ingin membangun cinta manusia sesuangguhnya.

Kehidupan manusia di dunia hanya sekedar ciptaan alam fisik, digerakan oleh alam fisik, dan tidak sedikitpun mengakui peran alam ruhani. Karenanya, apabila Freud menyebut alam psikis pada struktur kepribadian manusia maka sesuangguhnya aspek ini bukanlah yang dimaksud dengan aspek ruhani, sebab Freud tidak mengenal konsep ruhani dalam teori strukturnya.

Dari paparan di atas tampak, manusia dalam perspektif Freud tidak memiliki kebebasan untuk menentukan tingkah lakunya sendiri. Manusia adalah organisme yang tingkah lakunya dideterminasi oleh sejumlah determinan dan determinan manusia berasal dalam diri manusia sendiri (faktor internal/id). Sedangkan insting hewani adalah potensi yang tidak mendapat imbuhan, sehingga tetap dalam bentuknya

${ }^{6}$ Djamaludin Ancok dan Fuat Nashori Suroso, Psikologi Islami; Solusi Islam atas Problem-problem Psikologi, Yogyakarta: Pustaka Pelajar, 1994, h. 70-71.

${ }^{7}$ Calvin S. Hall and Gardner Lindzey, Theories of Personality, h. 127 
yang paling dangkal, tidak terolah, namun vegetatif perlu dipertahankan demi kelangsungan makhluk itu. ${ }^{8}$

Eksplanasi Freud tentang bentuk keabnormalan perilaku yang bersumber dari kekuatan IIbido tersebut menunjukan penjelasan yang dangkal, karena kekuatan dorongan tersebut telah membutakan manusia dan menjadikannya tidak berdaya untuk mengembangkan diri ke arah yang positif, tetapi mengarahkan kepada penyimpangan perilaku dalam upayanya mengatasi, menahan, dan menyiasati dorongan seksualnya. Manusia dalam ketidak berdayaannya melawan IIbidonya digambarkan oleh Freud menjadi wujud makhluk yang begitu pesimis dapat keluar dari belenggu impulsnya itu. 9

Padahal harus diakui bahwa manusia adalah wujud makhluk yang kompleks, memiliki begitu banyak dimensi kebutuhan untuk mengisi kehidupannya, sehingga seorang manusia tidak dapat hanya menjelaskan bahwa perilaku $\mathrm{X}$ adalah hasil dari suatu sebab kausal yang linier dari satu keadaan atau dorongan. Manusia merupakan makhluk yang begitu kompleks keinginan dan kebutuhannya, sehingga menjadi rumit pula untuk direka sumber dari pemikiran-pemikirannya serta tindakan-tindakannya. ${ }^{10}$

\section{Aliran Behaviorisme (Sikinner)}

Aliran yang menekankan teorinya pada perubahan tingkah laku manusia. Aliran ini menolak struktur kejiwaan manusia yang relatif stabil dan menetap. Ia berkeyakinan bahwa tingkah laku seseorang mudah berubah yang dipengaruhi oleh lingkungan sekitarnya. Skinner (1904-1990), pentolan utama behaviorisme, berpendapat bahwa perilaku manusia pada umumnya dapat dijelaskan berdasarkan teori pengkondisian operan (operant conditioning). ${ }^{11}$ Manusia berbuat sesuatu dalam lingkungannya untuk mendatangkan akibat-akibat, entah untuk mendatangkan pemenuhan kebutuhan atau menghindari datangnya hukuman atau pengalaman yang tidak enak. Segala tindakan manusia dapat dimengerti dalam kerangka pemikiran itu.

\footnotetext{
${ }^{8}$ A.A. Brill (ed.). The Basic Writing of Sigmund Freud, New York: Modern Library, 1966, h. 13.

${ }^{9}$ Calvin S. Hall and Gardner Lindzey, Theories of Personality, h. 131

${ }^{10}$ Choiruddin SP. Hadhiri, Klasifikasi Kandungan al-Quran, Jakarta: Gema Insani, 1995 h. 37

${ }^{11}$ Duane Schultz, Theories of Personality, Second Edition. California: Brooks/Cole Publishing Company, 1981, h.
} 


\section{Jurnal Asy-Syukriyyah}

Begitupula dengan JB. Watson (1878-1958), penggagas utama lahirnya aliran behaviorisme, mengatakan bahwa aksi dan reaksi manusia terhadap suatu stimulus hanyalah dalam kaitan dengan prinsip reinforcement (reward and punishment). Manusia tidak mempunyai will power. Ia hanyalah sebuah robot yang bereaksi secara mekanistik atas pemberian hukuman dan hadiah. Untuk itu, tugas utama psikolog adalah menciptakan atau mengkondisikan lingkungan yang kondusif untuk membentuk tingkah laku yang baik.

Ekspalani di atas menunjukan pula bahwa dinamika struktur kepribadian manusia tidaklah berbeda dengan dinamika hewan. Temuan-temuan yang dihasilkan dari penelitian hewan dalam aliran ini seringkali diaplikasikan untuk menelaah konsep manusia, padahal tingkah laku hewan itu sangat jauh berbeda dengan tingkah laku manusia, baik dilihat dari sisi asumsi maupun makna tingkah laku yang diperbuat. Teori strukturnya diasumsikan dari konsep manusia yang netral (kosong), tidak memiliki potensi bawaan apapun. Tingkah laku yang ada merupakan wujud dari kebiasaankebiasaan yang dibentuk oleh lingkungan.

Konsep manusia dalam pandangan aliran ini, diyakini hanya dapat diamati dan diukur melalui pendekatan terhadap persoalan fisik dan teknis semata. Manusia hanya dianggap sebagai obyek yang cukup diamati, tak perlu diwawancarai untuk memperoleh informasi tentang dirinya, perasaan-perasaannya serta hasrat dan keinginannya diingkari. Totalitas, kompleksitas dan keunikan manusia dipandang sebagai suatu yang sederhana oleh aliran behaviorisme. ${ }^{12}$

\section{Aliran Humanistik}

Aliran ini menekankan pada kekuatan dan keistimewaan manusia. Manusia lahir dengan citra dan atribut yang baik dan dipersiapkan untuk berbuat yang baik pula. Di antara citra baik itu adalah sifat-sifat dan kemampuan khusus manusia seperti berpikir, berimaginasi, bertanggung jawab dan sebagainya. Orientasi aliran ini lebih menekankan pada pola-pola kemanusiaan, sehingga ia lebih dikenal sebagai aliran yang berpaham humanisme. Psikologi humanistik hadir untuk mengkritisi kedua aliran sebelumnya yang dipandang telah melakukan dehumanisasi yang menafikan citra unik

${ }^{12}$ Septi Gumiandri "Kepribadian Manusia Dalam Perspektif Psikologi Islam" dalam Jurnal Holistik Vol 12, No. 1, Cirebon: CV. Pangger, 2011, h. 273 
manusia. Tekanan utama yang oleh behavioris dikenakan pada stimuli dan tingkah laku yang teramati serta pandangan pesimis terhadap hakekat manusia dan dicerminkan oleh psikoanalisis Freud, dipandang Psikologi Humanistik sebagai penyederhanaan yang keterlaluan, yang melalaikan diri manusia sendiri dan pengalaman-pengalaman batinnya, serta tingkah laku manusia yang kompleks seperti cinta, nilai-nilai dan kepercayaan, begitu pula potensinya untuk mengarahkan diri dan mengaktualisasikan diri.

Psikologi humanistik sangat mementingkan diri (self) manusia sebagai pemersatu yang menerangkan pengalaman-pengalaman subjektif individual, yang banyak menentukan tingkah lakunya yang dapat diamati. Sehubungan dengan ini, psikolog-psikolog self humanistik jauh lebih dekat kepada konsep dualistik psikofisikal agama: jasmani manusia versus jiwa atau pikirannya. ${ }^{13}$

Psikolog-psikolog Humanistik pun tidak menyetujui pandangan pesimis terhadap hakekat manusia yang dicerminkan oleh psikoanalisis Freud maupun pandangan netral (tidak jahat dan tidak baik) kaum behavior. Menurut psikologpsikolog humanistik, kedua aliran itu memandang tingkah laku manusia secara salah yaitu sebagai tingkah laku yang seluruhnya ditentukan oleh kekuatan-kekuatan diluar kekuasaannya; apakah kekuatan-kekuatan itu berupa motif-motif yang tak disadari atau conditioning dari masa kanak-kanak dan pengaruh lingkungan.

Bertentangan dengan kedua pandangan aliran tadi, aliran Humanistik ini meyakini sebuah konsep yang jauh lebih positif mengenai hakekat manusia, yakni memandang hakekat manusia itu pada dasarnya baik. Perbuatan-perbuatan manusia yang kejam dan mementingkan diri sendiri dipandang sebagai tingkah laku patologik yang disebabkan oleh penolakan dan frustasi dari sifat yang pada dasarnya baik itu. Seorang manusia tidak dipandang sebagai mesin otomat yang pasif, tetapi sebagi peserta yang aktif yang mempunyai kemerdekaan memilih untuk menentukan nasibnya sendiri dan nasib orang lain. ${ }^{14}$

Namun oleh karena aliran ini sangat menggantungkan teori strukturnya pada kekuatan manusia, sehingga orientasi filsafatnya cenderung mengarah pada

${ }^{13}$ Djamaludin Ancok dan Fuat Nashori Suroso, Psikologi Islami, h. 68-69.

${ }^{14}$ Bastaman, Dari antroposentris ke antropo-religius-sentris; Telaah Kritis atas Psikologi Humanistik" dalam Membangun Paradigma Psikologi Islami, Yogyakarta: Sipress, 1994, h. 78-87. 


\section{Jurnal Asy-Syukriyyah}

antroposentris (antropos = manusia; sentris = pusat), yakni pandangan yuang menempatkan manusia sebagai pusat segala pengalaman dan relasi-relasinya, serta penentu utama semua peristiwa yang menyangkut masalah manusia dan kemanusiaan. Berangkat dari filosofi ini, aliran ini akhirnya terjebak pada sikap optimisme yang berlebihan, dimana manusia dengan kualitas dirinya semata dipandang, lewat beberapa proses penyadaran dan pengembangan kualitas diri, telah mampu keluar dari problematika yang menyelimutinya. ${ }^{15}$

Tidak disangkal, memang pandangan manusia akan selalu kembali kepada kebaikan, akan tetapi kemampuannya untuk kembali itu akan sangat tergantung kepada berbagai faktor; baik pendidikan, sosio-kulturnya, dan skala pemaknaan baik itu sendiri di lingkungan mana manusia itu berada. Untuk itu, dapat dikatakan bahwa, manusia akan selalu membutuhkan petunjuk dalam meniti kehidupannya. Begitupula halnya dengan aliran ini yang melihat manusia dengan pola dasar yang baik dan berpotensi tidak terbatas. ${ }^{16}$ Pandangan ini jelas sangat optimistik dan bahkan terlampau optimistik terhadap upaya pengembangan sumber daya manusia, sehingga manusia dipandang sebagai penentu tunggal yang mampu melakukan play-god (peran Tuhan).

Optimisme aliran ini dalam memandang manusia, tentu saja akan berdampak pada penekanan atau pendewaan masalah kuantitatif manusia itu sendiri, dimana ia mencoba menafikan keterpenjaraannya oleh dualisme subjek-objek. Dari sini timbullah sifat arogansi kebermanusiaan sebagai penentu tunggal atas diri dan lingkungannya. Aliran ini terlalu memperhatikan kesadaran diri dan kemauan bebas manusia yang mutlak. Akibatnya, pertanyaan tentang: akan dibawa kemana hari depan umat manusia ini, sangatlah tergantung pada keinginan dan kehendak mutlak manusia itu sendiri tanpa merasa ada piranti pembatas atas segala tindakan-tindakannya. ${ }^{17}$

Untuk itu, hadirnya orientasi theosentris (Allah centris) ini diharapkan selain akan mencegah perkembangan ekstrim anthroposentris dalam psikologi Humanistik,

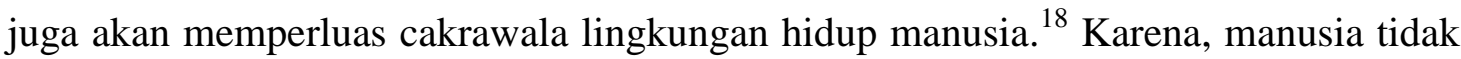

\footnotetext{
${ }^{15}$ Arthur Reber, Dictionary of Psychology. New York: Penguin Books, 1985, h. 195

${ }^{16}$ Djamaludin Ancok dan Fuat Nashori Suroso, Psikologi Islami, h.68-69

${ }^{17}$ Septi Gumiandri "Kepribadian Manusia Dalam Perspektif Psikologi Islam", h. 275

${ }^{18}$ Bastaman, Dari antroposentris ke antropo-religius-sentris, h. 87.
} 
saja melakukan relasi horisontal dengan alam (diri sendiri dan lingkungannya), tetapi juga menegakkan relasi transedental dengan Tuhan. Untuk itu, konsep-konsep seperti fitrah ketuhanan, keimnanan dan ibadah perlu diintroduksi pada Psikologi Humanistik, disamping mengintegrasikan dan mengukuhkan dimensi spiritual dalam sistem dimensional somato-psikho-sosiokultural seperti dianut sekarang, sehingga eksistensi manusia menjadi unitas dari dimensi somato-psikho-sosi-kultural-spiritual Ilahi.

Perkembangan selanjutnya, begitu 'menyegarkan' bagi kaum psikolog muslim, dimana dunia psikologi tidak sepenuhnya berisi paham psikologi nihilis sebagaimana terurai di atas dengan hadirnya madzhab psokologi di bawah ini.

\section{Aliran Transpersonal (Anthony Sutich)}

Telah hadir suatu mazhab psikologi Transpersonal yang dalam banyak hal mendasar berbeda dengan ketiga mazhab sebelumnya. Atas kritik dan penyempurnaan terhadap mazhab-mazhab psikologi sebelumnya, psikologi transpersonal lahir sebagai kelanjutan dari psikologi humanistik dan dapat dikatakan menjadi mazhab keempat dalam dunia psikologi. Psikologi transpersonal berusaha untuk menggabungkan tradisi psikologis dengan tradisi agama-agama besar dunia. Ia ingin menguak pesan terdalam dari semangat agama yang sering dilupakanbahkan oleh pemeluknya sendiri, yaitu sophia perennis.

Bila ditelusuri alur sejarah lahirnya aliran ini, pada dasarnya ia hadir diprakarsai oleh tokoh-tokoh psikologi yang prihatin terhadap kondisi masyarakat Barat modern waktu itu yang hidup dalam gelimang materi tetapi miskin secara spiritual. Dapat disebutkan disini misalnya Anthony Sutich (1907-1976), pendiri The Journal of Humanistic Psychology, sebagai pendiri mazhab psikologi transpersonal.

Bersama tokoh-tokoh psikologi humanistik lainnya, Sutich mendirikan The Journal of Transpersonal Psychology (JTP) pada tahun 1969. Jurnal ini mulai mengarahkan perhatiannya pada dimensi spiritual manusia. Penelitian yang dilakukan untuk memahami gejala-gejala ruhaniah seperti peak experience, pengalaman mistis, ekstasi, kesadaran ruhaniah, kesadaran kosmis, aktualisasi transpersonal pengalaman spiritual dan kecerdasan spiritual. ${ }^{19}$

${ }^{19}$ Danah Zohar dan Ian Marshall, Spiritual intelligence: The Ultimate Intelligence, London: Bloomsbury, 2000, h 9. 


\section{Jurnal Asy-Syukriyyah}

Seperti halnya psikologi humanistik, psikologi transpersonal juga menaruh perhatian pada dimensi spiritual manusia, hanya bedanya adalah kalau psikologi humanistik lebih memanfaatkan potensi-potensi ini untuk peningkatan hubungan antar manusia, sedangkan psikologi transpersonal lebih tertarik untuk meneliti pengalaman subjektif-transendental, serta pengalaman luar biasa dari potensi spiritual manusia ini. Gambaran selintas tentang psikologi transpersonal ini menunjukkan bahwa aliran ini mencoba untuk menjajagi dan melakukan telaah ilmiah terhadap suatu dimensi yang sejauh ini lebih dianggap sebagai bidang garapan kaum kebatinan, ruhaniawan, agamawan, dan mistikus. Sekalipun masih dalam taraf telaah awal, Psikologi transpersonal menunjukkan bahwa di luar alam kesadaran biasa terdapat ragam dimensi lain yang luar biasa potensialnya.

Dari paparan di atas dapat dipahami, bahwa dalam perspektif aliran ini, struktur kepribadian manusia tidaknya terdiri unsur fisik ataupun psikhis semata, tapi juga mengandung unsur spiritual. Dan dari Tri determinan; raga, psikis dan spiritual yang eksis dalam diri manusia, dimensi spirituallah yang merupakan dimensi pembeda antara manusia dengan makhluk-makhluk lainnya. ${ }^{20}$ Dimensi ini bukan terletak dalam alam tak sadar dalam artian konvensionalpsikoanalisis, melainkan bertempat di atas sadar, dalam artian supraconsciousness, yang merupakan kelanjutan dari alam sadar (theconsciousness), menurut istilah psikhoanalisis. ${ }^{21}$ Dimensi spiritual ini, dalam perspektif salah satu tokoh aliran psikologi transpersonal, Viktor E. Frankl dalam Gumiandri, mengejawantah ke alam sadar dan benar-benar dapat dialami dan disadari manusia, meskipun bagi sebagian besar masih belum teraktualisasi atau masih merupakan potensialitas yang tidak disadari. Namun sekalipun dimensi ini semula "terletak" di alam tak sadar, tetapi tidak sama dan tidak ada hubungannya dengan insting-insting primer yang juga "tersimpan" dalam alam tak sadar. Sebuah pandangan yang cukup revolusioner mengenai manusia dan kesadarannya. ${ }^{22}$

Pandangan spiritual yang dieksplorasi oleh aliran transpersonal ini memang terlihat serupa dengan pandangan Islam mengenai manusia yang memiliki unsur

${ }^{20}$ Septi Gumiandri “Kepribadian Manusia Dalam Perspektif Psikologi Islam”, h. 278

${ }^{21}$ Viktor E. Frankl, Man's Search For Meaning; An Introduction To Logotherapy, London: Eight Impression, Hodder and Stoughton, Ltd., 1997, h. 159

${ }^{22}$ Septi Gumiandri "Kepribadian Manusia Dalam Perspektif Psikologi Islam”, h. 278 
ruh/spiritual disamping raga dan jiwanya. Tetapi sayangnya, Ruh sebagai salah satu unsur dari Tri determinan manusia yang sejauh ini dianut oleh aliran transpersonal sebagai penentu corak kepribadian, ternyata bukanlah ruh yang dimaksud dalam artian Islam. Sedangkan ruh dalam perspektif Islam adalah ruh yang dikurniakan Tuhan kepada manusia bukan sembarang ruh, melainkan ruh yang suci dan sangat luhur.

Meski tidak diragukan bahwa aliran ini sering menyebut dan mengakui adanya daya spiritual dalam struktur kepribadian manusia, namun spiritual yang dimaksud disini bukanlah agama, tetapi sebatas pada ketergantungan manusia pada sesuatu yang belum atau tidak realistik. Sebagaimana ungkapan Frankl, bahwa maksud spiritual yang ia maksud tidak mengandung arti agama.

Spiritual diartikan sebagai inti kemanusiaan dan sebagai sumber makna hidup dan potensi dari berbagai kemampuan dan sifat luhur manusia yang luar biasa. Spiritual dalam perspektif aliran ini hanyalah aspirasi manusia untuk hidup bermakna, dan sumber dari kualitas-kualitas insani. ${ }^{23}$ Pemaknaan ini tentu saja berbeda dengan makna ruh dalam perspektif Islam yang sangat latif, ruhaniyyah dan rabbaniyyah. ${ }^{24}$ Dan oleh karena ia seperti halnya para psikolog lainnya yang menggantungkan teorinya pada metode penelitian ilmiah, maka pada gilirannya, temuannyapun sebatas pada pengalaman spiritual versi ilmiah. Ada satu hal yang dilupakan Frankl yakni bahwa pengalaman spiritual itu baru akan menampakan fungsinya apabila ia melibatkan diri secara langsung, bukan sekedar mengamati belaka. Oleh sebab itu, pengalaman spiritual setidak-tidaknya didekati dengan metode ilmiah-profetik agar hasilnya dapat dirasakan dan bukan sekedar digambarkan.

Untuk itu, sebagaimana diungkap Bastaman, Sukanto dan A. Dardiri Hasyim, diharapkan pengembangan Psikologi setelah ini mengalami kelanjutan dalam pemaknaan terhadap ruh tersebut dan Islam merupakan rujukan pelengkap diskursus ini. $^{25}$ Lebih lanjut Bastaman melihat fenomena metafisika dalam pemikiran psikolog transpersonal ini sebagai dimensi metapsikologis tingkat I yang merupakan kelanjutan alam sadar (the consciousness) dengan asumsi masih ada kelanjutannya yang mungkin

\footnotetext{
${ }^{23}$ Viktor E. Frankl, Man's Search For Meaning, h. 160

${ }^{24}$ Abu Hamid Muhammad al-Ghaza>li>, Ihya $>$ ' $U l u>m$ al-Di>n, Beirut : Dâr al-Fikr, 1980, Juz III, h. 5

${ }^{25}$ Bastaman, Integrasi Psikologi dengan Islam; Menuju Psikologi Islami, Yogyakarta: Pustaka Pelajar, 1995. h. 39
} 
belum tersentuh oleh psikologi kontemporer, namun sebenarnya bisa dilengkapi bila merujuk pada disiplin ilmu Tasawuf yang banyak mengkaji masalah-masalah ruh dan keruhanian manusia. $^{26}$

\section{Kepribadian Manusia Perspektif Al-Quran}

Manusia dalam pandangan psikologi Islam dinilai sebagai makhluk unik dan istimewa dalam bahasa al-Quran khalqan a>khar. Ia adalah makhluk two in one atau makhluk satu wujud dua dimensi, yaitu bahwa manusia adalah makhluk yang terdiri dari dua dimensi, yaitu jasmani dan rohani. Di dalam dirinya tertanam sifat mengakui adanya Tuhan, memiliki kebebasan, amanah, tanggungjawab dan kecenderungan ke arah kebaikan. Eksistensinya dimulai dari keadaan lemah yang kemudian bergerak ke arah kekuatan yang sangat dahsyat. ${ }^{27}$

\section{Konsep Ruh $(a l-R u>h)$}

Kata al-ruh terulang sebanyak 24 kali dalam al-Quran, masing-masing terdapat dalam 19 surat yang tersebar dalam 21 ayat. Term al-ruh dalam al-Quran memiliki tiga makna, yaitu pertolongan, jibril dan ruh manusia itu sendiri. Ada 5 ayat yang menunjukkan arti ruh manusia secara langsung yaitu; Qs. [15]: 29; [17]: 85; [17]: 85 ; [32]: 9 dan [38]: $72 .^{28}$

Menurut al-Raghif al-Isfahani (w. $1108 \mathrm{M}$ ) diantara makna al-ruh adalah al-nafs yaitu jiwa manusia. Dalam arti aspek atau dimensi, yaitu sebagian dari aspek atau dimensi manusia adalah al-ruh. Hal ini dapat dipahami dari analogi yang digunakannya yang menyamakannya dengan al-insan adalah hayawan, yaitu salah satu sisi manusia adalah sisi kebinatangan. Maka manusia disebut sebagai hewan yang berbicara (hayawan al-natiq). ${ }^{29}$

M. Quraish Shihab menyebutkan bahwa dengan ditiupkannya ruh kepada manusia, maka manusia menjadi makhluk yang istimewa dan unik, yang berbeda

\footnotetext{
${ }^{26}$ Bastaman, Dari antroposentris ke antropo-religius-sentris, h. 83.

${ }^{27}$ Baharuddin Hasibuan, Paradigma Psikologi Islami: Studi tentang Elemen Psikologi dari al-
} Qur'an, Yogyakarta: Pustaka Pelajar, 20004, h. 293 213.

${ }^{28}$ Fuad Abdul Baqi, Mu'jam al-Mufakhras li Alfaz al-Quran al-Karim, Beirut: Dar al-Fikr, 1981, h.

${ }^{29}$ Al-Raghif al-Isfahani, Mu'jam Mufradat al-faz al-Quran, Beirut: Dar al-Fikr, t.th, h. 210. 


\section{Jurnal Asy-Syukriyyah}

dengan makhluk lainnya. Sedangkan al-nafs juga dimiliki oleh makhluk lainnya, seperti orang hutan. Kalau demikian, al-nafs bukan unsur yang menjadikan manusia makhluk yang unik dan istimewa. ${ }^{30}$

Berikut ini adalah ayat-ayat al-Quran menyebutkan al-ruh yang bermakna ruhaniyah manusia, yaitu QS al-Hijr [15]:29 ;

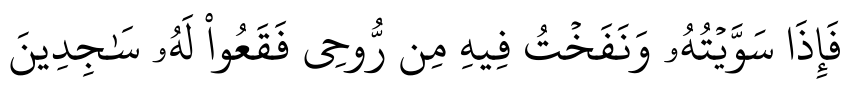

"Maka apabila Aku telah menyempurnakan kejadiannya, dan telah meniup kan kedalamnya ruh (ciptaan)-Ku, maka tunduklah kamu kepadanya dengan bersujud"

Kemudian pada QS Al-Isra' [17]:85 disebutkan dua kali

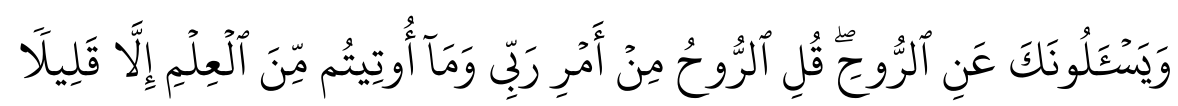

"Dan mereka bertanya kepadamu tentang roh. Katakanlah: "Roh itu termasuk urusan Tuhan-ku, dan tidaklah kamu diberi pengetahuan melainkan sedikit"

QS al-Sajadah [32]: 9:

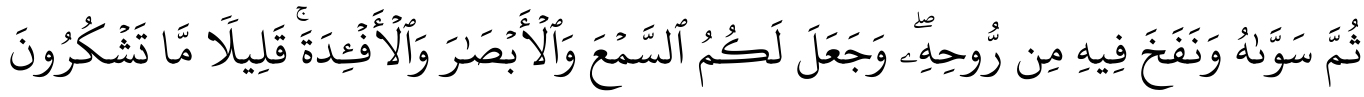

"Kemudian Dia menyempurnakan dan meniupkan ke dalamnya roh (ciptaan)-Nya dan Dia menjadikan bagi kamu pendengaran, penglihatan dan hati; (tetapi) kamu sedikit sekali bersyukur"

QS Sha>d [38]:72

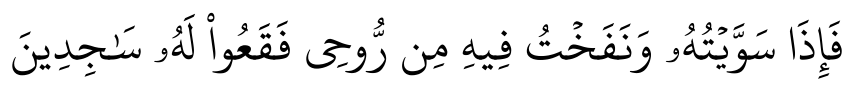

"Maka apabila telah Kusempurnakan kejadiannya dan Kutiupkan kepadanya roh (ciptaan)Ku; maka hendaklah kamu tersungkur dengan bersujud kepadanya"

${ }^{30}$ M. Quraish Shihab, Wawasan al-Quran: Tafsir Maudhui atas Pelbagai Persoalan Umat, Bandung: Mizan, 2000, h. 293 


\section{Jurnal Asy-Syukriyyah}

Beberapa ayat tersebut di atas mengisyaratkan bahwa al-ruh berbeda dengan al-nafs. Sebab al-nafs memiliki pengertian secara umum unsur material dan immaterial. Sebagaimana dijelaskan dalam Qs. Al-Mukminun [23]: 12-14

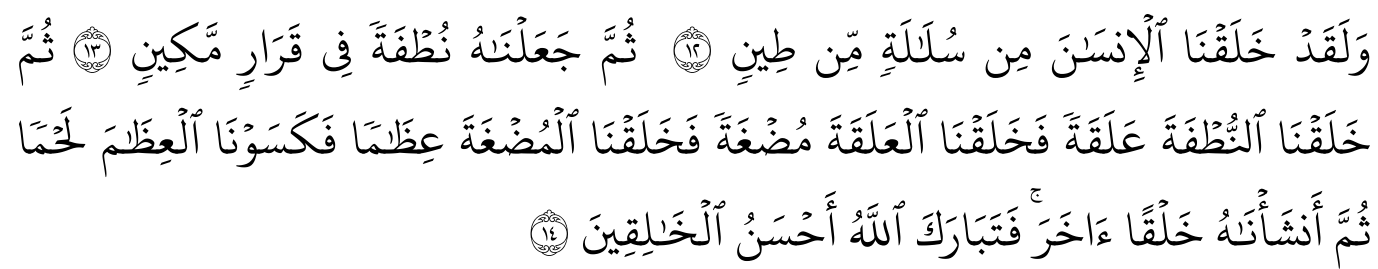

"Dan sesungguhnya Kami telah menciptakan manusia dari suatu saripati (berasal) dari tanah 13. Kemudian Kami jadikan saripati itu air mani (yang disimpan) dalam tempat yang kokoh (rahim) 14. Kemudian air mani itu Kami jadikan segumpal darah, lalu segumpal darah itu Kami jadikan segumpal daging, dan segumpal daging itu Kami jadikan tulang belulang, lalu tulang belulang itu Kami bungkus dengan daging. Kemudian Kami jadikan dia makhluk yang (berbentuk) lain. Maka Maha sucilah Allah, Pencipta Yang Paling Baik”

Istilah khalqan akhar pada ayat tersebut di atas mengisyaratkan bahwa manusia berbeda dengan makhluk lainnya, seperti hewan, karena di dalam jiwanya terdapat dimensi ruh. Proses perkembangan fisik dan jiwa manusia dalam ayat di atas sama dengan binatang. Tetapi semenjak manusia menerima ruh, maka ia menjadi lain karena ia memiliki ruh. ${ }^{31}$

Selanjutnya juga dapat dipahami bahwa dari ayat di atas, bahwa sejak terjadinya pembuahan, yaitu bertemunya sel spermatozoa dan ovum, maka kehidupan sudah dimulai. Karena ia telah hidup, maka ia telah memiliki nafs, sebab setiap yang hidup memiliki nafs atau nyawa. Sumber kehidupan air sebagaimana dijelaskan dalam ; ayat

Secara biologis air itu adalah air mani, berkembang melalui beberapa tahap:nutfah, alaqah, mudghah, izan dan khalqan akhar. Adanya pertumbuhan dan perkembangan ini secara logis cukup membuktikan bahwa kehidupan sudah ada, walaupun baru tahap permulaan. Kehidupan ini tercipta sebagai konsekuensi logis penciptaan fisik manusia. Jadi dengan diciptakannya fisik manusia, maka dengan

\footnotetext{
${ }^{31}$ Baharuddin Hasibuan, Paradigma Psikologi Islami, h. 137
} 
sendirinya akan tercipta kehidupannya. Pada tahapan ini nafs belum memiliki dimensi ruh, aql dan qalb. Pada saat ini nafs memiliki kesamaan dengan nafs yang ada pada binatang, seperti al-nafs orang hutan. Setelah al-nafs manusia menerima al-ruh, barulah ia menjadi makhluk yang berbeda dengan binatang. Setalah mengalami perkembangan secara sempurna dan lahir ke dunia, maka nafs yang memiliki ruh itu memiliki kesiapan untuk menerima daya, sam 'u, absar dan af'idah yang merupakan sarana-sarana bagi al-aql dan al-qalb untuk memperoleh pengertian dan pemahaman. ${ }^{32}$

Dari keseluruhan ayat yang menjelaskan tentang ruh tersebut juga dapat dipahami bahwa al-ruh itu memiliki hubungan kepemilikan dan asal dengan Allah. Hubungan kepemilikan dan asal tersebut mengisyaratkan bahwa ruh merupakan dimensi jiwa manusia yang bernuansa ilahiyah. Implikasinya dalam kehidupan manusia adalah aktulisasi potensi luhur batin manusia berupa keinginan mewujudkan nilai-nilai ilahiyah yang tergambar dalam al-asma al-husna (namanama Allah) dan berperilaku agama (makhluk agamis). Ini sebagai konsekuensi logis dimensi al-ruh yang berasal dari Allah, maka ia memiliki sifatsifat yang dibawa dari asalnya tersebut.

Lebih dari itu, tetapi kebutuhan agama juga merupakan suatu hal yang logis. Dalam agama, keyakinan terhadap Allah dapat dipenuhi dan dipuaskan. Disini dapat dijelaskan bahwa mengapa manusia memerlukan agama. Sekaligus menolak pandangan psikolog psikoanalisa, behaviorisme yang menganggap orang beragama sebagai orang yang mengidap penyakit jiwa. Hal ini dapat dipahami karena kedua mazhab psikologi tersebut tidak mengakui agama sebagai kebutuhan jiwa manusia, namun sebaliknya menganggap agama sebagai gangguan dan penyakit jiwa. ${ }^{33}$

Jika dihubungkan dengan dimensi jiwa manusia, maka al-ruh merupakan dimensi spiritual yang menyebabkan jiwa manusia dapat dan memerlukan hubungan dengan hal-hal yang bersifat spiritual. Jiwa manusia memerlukan hubungan dengan Tuhan. Kecuali itu, jiwa juga memiliki daya-daya atau kekuatankekuatan yang sifatnya spiritual yang tidak dimiliki oleh makhluk lainnya. Ini

\footnotetext{
${ }^{32}$ Baharuddin Hasibuan, Paradigma Psikologi Islami, h. 139

${ }^{33}$ Baharuddin Hasibuan, Paradigma Psikologi Islami, h. 146
} 
semua sebagai akibat karena manusia memiliki dimensi yang bersumber dari Tuhan.

Dengan demikian dapat dijelaskan bahwa ruh merupakan dimensi jiwa manusia yang sifatnya spiritual dan potensi yang berasal dari Tuhan. Dimensi ini menyebabkan manusia memiliki sifat ilahiyah dan mendorong manusia untuk mewujudkan sifat Tuhan itu di dalam kehidupan dunia. Di sinilah fungsinya sebagai khalifah dapat teraktualisasikan. Karena itu, manusia menjadi makhluk yang semi samawi-ardhi, yaitu makhluk yang memiliki unsur-unsur alam dan potensi-potensi ketuhanan.

2. Dimensi Kalbu (al-Qolb)

Terkait dengan dimensi ini, Al-Ghazali membagi pengertian Kalbu menjadi dua; yaitu kalbu yang bersifat jasmani dan kalbu yang bersifat ruhani. Kalbu jasmani adalah salah satu organ yang terdapat di dalam tubuh manusia berupa segumpal daging yang berbentuk seperti buah sanubar (sanubari) atau seperti jantung pisang yang terletak di dalam dada sebelah kiri. Kalbu ini lazimnya disebut jantung. Sedangakan kalbu ruhani adalah sesuatu yang bersifat halus (lathif), rabbani dan ruhani yang berhubungan dengan kalbu jasmani. Bagian ini merupakan esensi manusia. $^{34}$

Kalbu dalam pengertian pertama erat hubungannya dengan ilmu kedokteran dan tidak menyangkut maksud-maksud agama serta kemanusiaan. Kalbu dalam artian pertama ini juga ada pada hewan. Sedang Kalbu dalam arti kedua adalah menyangkut jiwa yang bersifat halus, ruhaniah, ketuhanan, yang mempunyai hubungan dengan Kalbu Jasmani. ${ }^{35}$

Daya kalbu tidak terbatas pada pencapaian kesadaran, tetapi mampu mencapai tingkat supra-kesadaran. Kalbu mampu menghantarkan manusia pada tingkat spiritualitas, keagamaan dan ketuhanan. Semua tingkatan itu merupakan tingkatan suprakesadaran manusia, sebab kedudukannya lebih tinggi daripada rasio manusia. Manusia dengan kalbunya mampu membenarkan wahyu. Kebenaran wahyu ada yang bersifat rasional dan ada pula yang bersifat supra- rasional. Sifat

\footnotetext{
${ }^{34}$ Imam Al-Ghazali , Ihya' 'Ulum al-Din, h. 3

${ }^{35}$ Amir al-Najjar, Ilmu Jiwa dalam Tasawuf. Jakarta: Pustaka Azzam, 2001\, h. 60.
} 
rasional dapat ditangkap oleh daya akal manusia, sedang sifat supra-rasional hanya dapat ditangkap oleh kalbunya. Dengan begitu, fungsi kalbu bukan sekedar merasakan sesuatu, melainkan juga berfungsi untuk menangkap pengetahuan yang bersifat supra-rasional. ${ }^{36}$

3. Dimensi Akal (al-'Aql)

Akal bukanlah kalbu. Ia merupakan dimensi tersendiri dalam aspek nafsiyah yang berkedudukan di otak yang berfungsi untuk berpikir. Akal memiliki kesamaan dengan kalbu dalam memperoleh daya kognisi, tetapi cara dan hasilnya berbeda. Akal mampu mencapai pengetahuan rasional tetapi tidak mampu mencapai pengetahuan yang supra-rasional. Akal mampu mengungkap hal-hal yang abstrak tetapi belum mampu merasakan hakikatnya. Akal mampu menghantarkan eksistensi manusia pada tingkat kesadaran tetapi tidak mampu mengahantarkan pada tingkat supra-kesadaran. ${ }^{37}$

Menurut al-Ghazali, akal memiliki banyak aktifitas; al-Nadlar (melihat dengan memperhatikan); al-Tadabbur (memperhatikan dengan seksama); alTa'ammul (merenungkan); al-Istibshâr (melihat dengan mata bathin); al-I'tibâr (menginterpertasikan); al-Tafkîr (memikirkan); dan al-Tadzakkur (mengingat). ${ }^{38}$

4. Dimensi Nafsu (al-Nafs)

Nafsu dalam terminologi psikologi dekat dengan sebutan konasi (daya karsa). Konasi (kemauan) adalah bereaksi, berbuat, berusaha, berkemauan, dan berkehendak. Terkait dengan diskursus tersebut, Imam al-Ghazali berpendapat bahwa di dalam diri manusia terdapat empat potensi (1) potensi nafsu Hayawaniyyah, yaitu kecenderungan pada perilaku hewan ternak. Nafsu ini identik dengan laku hidup binatang ternak dalam hal mencari kepuasan lahiriah atau kepuasan seksual, seperti tamak, tidak punya rasa malu dan lain sebagainyanya. (2) potensi nafsu Sabu'iyyah, yakni nafsu yang mendorong kepada perilaku binatang buas. Contohnya adalah seorang yang senang menindas orang lain, senang memakan hak orang lain, senang untuk menyerang orang lain, dan segala perilaku

\footnotetext{
${ }^{36}$ Amir al-Najjar, Ilmu Jiwa dalam Tasawuf, h. 61

${ }^{37}$ Imam Al-Ghazali , Ihya' 'Ulum al-Din, h. 3

${ }^{38}$ Septi Gumiandri “Kepribadian Manusia Dalam Perspektif Psikologi Islam”, h. 285
} 
yang penuh dengan kebencian, permusuhan, dengki, amarah dan saling hantam (3) potensi nafsu Syaithaniyyah; nafsu yang mewakili tabiat syaitan yang mengajak manusia ke jalan kesesatan. Nafsu ini mendorong manusia untuk membenarkan segala kejatahan yang dilakukan. ${ }^{39}$

Meskipun tampak dari gambaran nafsu diatas, bahwa manusia begitu terkondisi dari impuls dan bawaan insting nafsunya, namun al-Ghazali melihat adanya satu potensi lain dari diri manusia yang tidak termasuk dalam kategori hawa nafsu, ia adalah kekuatan-Tuhan (quwwatan Rabbaniyah). Kekuatan Tuhan adalah Kekuatan yang berasal dari percikan cahaya Ilahi. Kekuatan ini terletak dalam akal sehat manusia. Dengan menggunakan kekuatan ini, manusia dapat menundukkan ketiga kekuatan di atas. ${ }^{40}$ Dengan digunakannya akal sehat, maka manusia akan dapat memilah-milah mana perbuatan yang sejalan dengan perintah Allah dan mana perbuatan yang melenceng dari ketentuan Allah. Akal akan membimbing untuk menempuh perjalanan ruhani menuju Allah SWT.

Nafs dalam al-Qur'ân tidak disebutkan untuk substansinya sendiri, sedangkan Kalbu untuk substansinya sendiri sehingga tidak dikaitkan dengan badan. Nafs bersifat seperti tanah (al-Thinîyyah) dan api (al-Nâriyyah) sedangkan kalbu bersifat cahaya (nuriyah) dan besifat ruhani (al-Rûhâniyyah).

Dimensi rohani yang disebut dengan al-nafs (jiwa) yang memiliki unsur-unsur; al-nafs, al-aql, al-qalb, dan al-ru>h. Unsur-unsur ini membentuk struktur yang sistematis, utuh, integritas dan sempurna, inilah struktur jiwa manusia dalam pandangan psikologi Islam.

Ruh dalam konsep pendidikan Islam merupakan dimensi psikis manusia yang bersumber secara langsung dari Tuhan. Dimensi ruh ini membawa sifat-sifat dan dayadaya yang dimiliki oleh sumbernya, yaitu Allah. Perwujudan dari sifat-sifat dan dayadaya itu pada gilirannya memberikan potensi secara internal di dalam dirinya untuk menjadi khalifah Allah (wakil Allah). Khalifah Allah dapat berarti mewujudkan sifatsifat Allah secara nyata dalam kehidupannya di bumi untuk mengelola dan memanfaatkan bumi Allah. Tegasnya bahwa dimensi al-ru>h merupakan daya potensialistas internal dalam diri manusia yang akan mewujud secara aktual sebagai

\footnotetext{
${ }^{39}$ Amir al-Najjar, Ilmu Jiwa dalam Tasawuf, h. 62

${ }^{40}$ Usman Najati, Al-Quran dan Psikologi, Jakarta: Aras Pustaka, 2001, h. 181
} 
khalifah Allah. Sedangkan dimensi fitrah mewujudkan fungsi $i b a>d a h$. Konsep ibadah ini juga yang menjadi motivasi utama manusia dalam berbuat sesuatu, sebagai konskeunsi logis dari pemenuhan kebutuhan yang tertinggi yaitu kebutuhan religius. ${ }^{41}$ sebagaimana disebutkan dalam QS.al-Dzariat [56].31

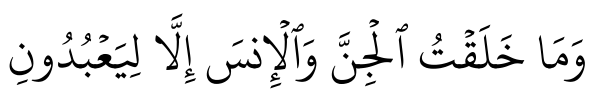

"Dan aku tidak menciptakan jin dan manusia melainkan supaya mereka mengabdi kepada-Ku”

Senada dengan itu, Hasan Langgulung mengatakan bahwa proses interaksi antara badan (al-jism) dengan ruh yang menghasilkan khalifah. Khalifah inilah yang membedakan antara manusia dengan makhluk lainnya, di samping dimensi al-fit\}rah dan al- 'aql yang kemudian dapat memikirkan sesuatu yang baik dan yang salah. Jadi $a l$-ru>h, al-fitrah dan al-'aql manusia merupakan modal dan potensi yang diberikan oleh Allah untuk menjadi khalifah dimuka bumi. ${ }^{42}$

Dimensi al-ru>h dan al-fitrah merupakan tempat bersarangnya bibit rasa keagamaan dan dimensi ini pula yang luput sama sekali dari jangkauan psikologi psikoanalisis, behaviorisme dan humanistik. Ketiga mazhab psikologi Barat tersebut dalam memandang struktur psikis manusia nampak bahwa konsep yang dikedepankan masih reduksionis, terpenggal, parsial dan belum selesai. Psikologi Islam yang membangun konsep struktur manusia berdasarkan pemahaman dan sangat penting memahami apa (ontologi), bagaimana (epistemologi), dan untuk apa (aksiologi) pengetahuan manusia. Memahami ilmu, filsafat, dan agama dengan baik dapat membantu untuk melihat kekhasan maupun persinggungan antara ketiga pengetahuan itu. Ketiga pengetahuan ini memiliki sumbangan masing-masing. Agama tetap bisa memberi makna yang lebih tinggi dan saling melengkapi dengan pandangan ilmiah dan filosofis karena agama berbicara dengan bahasa simbol dan mistis yang sangat memperkaya pandangan dunia.

${ }^{41}$ Baharuddin Hasibuan, Paradigma Psikologi Islami, h. 314

${ }^{42}$ Langgulung, Hasan, Manusia dan Pendidikan: Suatu Analisa Psikologis, Filsafat dan Pendidikan, Jakarta: Pustaka Al-Husna Baru, 2004, h. 30-31 


\section{Jurnal Asy-Syukriyyah}

\section{DAFTAR PUSTAKA}

Jujun S. Suriasumantri, Filsafat Ilmu: Sebuah Pengantar Populer, Jakarta: Pustaka Sinar Harapan, 2013, cet. ke-24,

Calvin S. Hall, A Primer of Freudian Psychology, New York: The World Publishing, 1954,

Calvin S. Hall and Gardner Lindzey, Theories of Personality,

A.A. Brill (ed.). The Basic Writing of Sigmund Freud, New York: Modern Library, 1966,

Choiruddin SP. Hadhiri, Klasifikasi Kandungan Al-Quran, Jakarta: Gema Insani, 1995

Duane Schultz, Theories Of Personality, Second Edition. California: Brooks/Cole Publishing Company, 1981

Septi Gumiandri “Kepribadian Manusia Dalam Perspektif Psikologi Islam” Dalam Jurnal

Holistik Vol 12, No. 1, Cirebon: CV. Pangger, 2011,

Djamaludin Ancok Dan Fuat Nashori Suroso, Psikologi Islami,

Bastaman, Dari Antroposentris Ke Antropo-Religius-Sentris; Telaah Kritis Atas Psikologi Humanistik" Dalam Membangun Paradigma Psikologi Islami, Yogyakarta: Sipress, 1994,

Arthur Reber, Dictionary Of Psychology. New York: Penguin Books, 1985,

Septi Gumiandri “Kepribadian Manusia Dalam Perspektif Psikologi Islam”,

Danah Zohar Dan Ian Marshall, Spiritual Intelligence: The Ultimate Intelligence, London:

Bloomsbury, 2000,

Viktor E. Frankl, Man's Search For Meaning; An Introduction To Logotherapy, London:

Eight Impression, Hodder And Stoughton, Ltd., 1997,

Abu Hamid Muhammad Al-Ghaza $>$ Li $>$, Ihya $>$ ' $U l u>M A l-D i>N$, Beirut : Dâr Al-Fikr, 1980, Juz III,

Bastaman, Integrasi Psikologi Dengan Islam; Menuju Psikologi Islami, Yogyakarta: Pustaka Pelajar, 1995. 